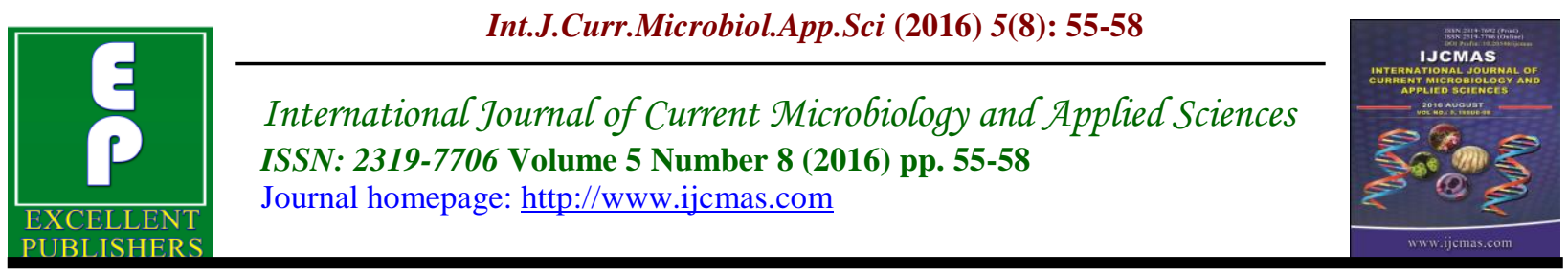

Original Research Article

http://dx.doi.org/10.20546/ijcmas.2016.508.006

\title{
Aecidium sp. causing Serious Leaf Rust on Cordia dichotoma G. Forst in Haryana-First Record
}

\author{
Narendra Kumar* and S.M. Paul Khurana \\ Amity Institute of Biotechnology, Amity University Haryana, Manesar-122413, \\ Gurgaon, Haryana, India \\ *Corresponding author
}

\begin{tabular}{|c|c|}
\hline & A B S T R A C T \\
\hline $\begin{array}{l}\text { Ke y w o r d s } \\
\text { Aecidium sp, } \\
\text { Cordia } \\
\text { dichotoma, } \\
\text { pathogenicity. }\end{array}$ & \multirow{3}{*}{$\begin{array}{l}\text { Aecidium sp. (Pucciniaceae) on Cordia dichotoma G. Forst is reported for } \\
\text { the first time from Panchgaon, Gurgaon Haryana which was observed in } \\
\text { February March 2014-16 having lesions on living leaves which were oval to } \\
\text { rounded, chlorotic, measuring } 4-14 \text { mm in diameter. Aecia were gregarious, } \\
\text { cupulate, yellowish and erumpent with a peridium having a lacerate, } \\
\text { somewhat recurved margin. After pathogenicity from pustules on healthy } \\
\text { leaves Aeciospores were recovered and examined under compound } \\
\text { microscope which showed to have identical morphology to those first } \\
\text { observed. }\end{array}$} \\
\hline Article Info & \\
\hline $\begin{array}{l}\text { Accepted: } \\
06 \text { July } 2016 \\
\text { Available Online: } \\
10 \text { August } 2016\end{array}$ & \\
\hline
\end{tabular}

\section{Introduction}

Cordia dichotoma G. Forst is a flowering tree from the borage family, Boraginaceae, that is native to the Indomalaya ecozone, northern Australia, and western Melanesia. Common names include fragrant manjack, snotty gobbles, glue berry, anonang, pink pearl, bird lime tree, Indian cherry, Lasuda Tenti(Panjabi), Dela or Gonda (Hindi), Lasura (Nepali) and Bhokar (Marathi). Traditionally it is also used for therapeutic uses such as anthelmintic, astringent, diuretic, demulcent, purgative, expectorant, tonic, ulcer and cough (Anjaria et al., 1997; Parekh and Chanda, 2007; Khond et al., 2009).
On February March 2014-16, rust symptoms were observed on Cordia dichotoma (Fig,1) growing in Amity University Haryana campus Panchgaon, Gurgaon situated at $28.47^{\circ}$ North latitude, $77.03^{\circ}$ East longitude and 216 meters elevation above the sea level. In more than 24 trees (8 small, 8 medium and 8 large sized groups) the rust symptoms were found to be present on leaves, floral axes and petioles and even on stems of small size young wild plants upto 1 meter height. The Lesions on living leaves were oval to rounded, chlorotic, measuring 4-14 $\mathrm{mm}$ in diameter later on turning dark and coalescing, affecting large areas of the lamina adaxially. 
The first symptom was small and pale yellow spots on the upper surfaces of the leaves. As the spots increased in size, these turned brown. Bright yellow powdery masses of spores were produced in tiny cuplike structures that appeared on the undersurface of leaves and the surface of floral axes and petioles. Aecia were gregarious, cupulate, yellowish, and erumpent with a peridium having a lacerate, somewhat recurved margin. Peridial cells were hyaline to whitish, rhomboidal, 16 to 24 (avg. 19.5) $\times 14$ to 19 (avg. 16) $\mu \mathrm{m}$, smooth to finely verrucose, but not observed in aecial stage on floral axes and petioles. Aeciospores were globose to ellipsoid, 13 to 15 (avg. 14.4) $\times 14$ to 15.0 (avg. 14) $\mu \mathrm{m}$, hyaline to yellowish, with many verrucose surface and hyaline walls (Fig 1,b,c). Aecidium sp.infection was also found to be present on old leaves (Fig 1d).

Fig.1A Healthy and Aecidium sp infected plant of Cordia dichotoma

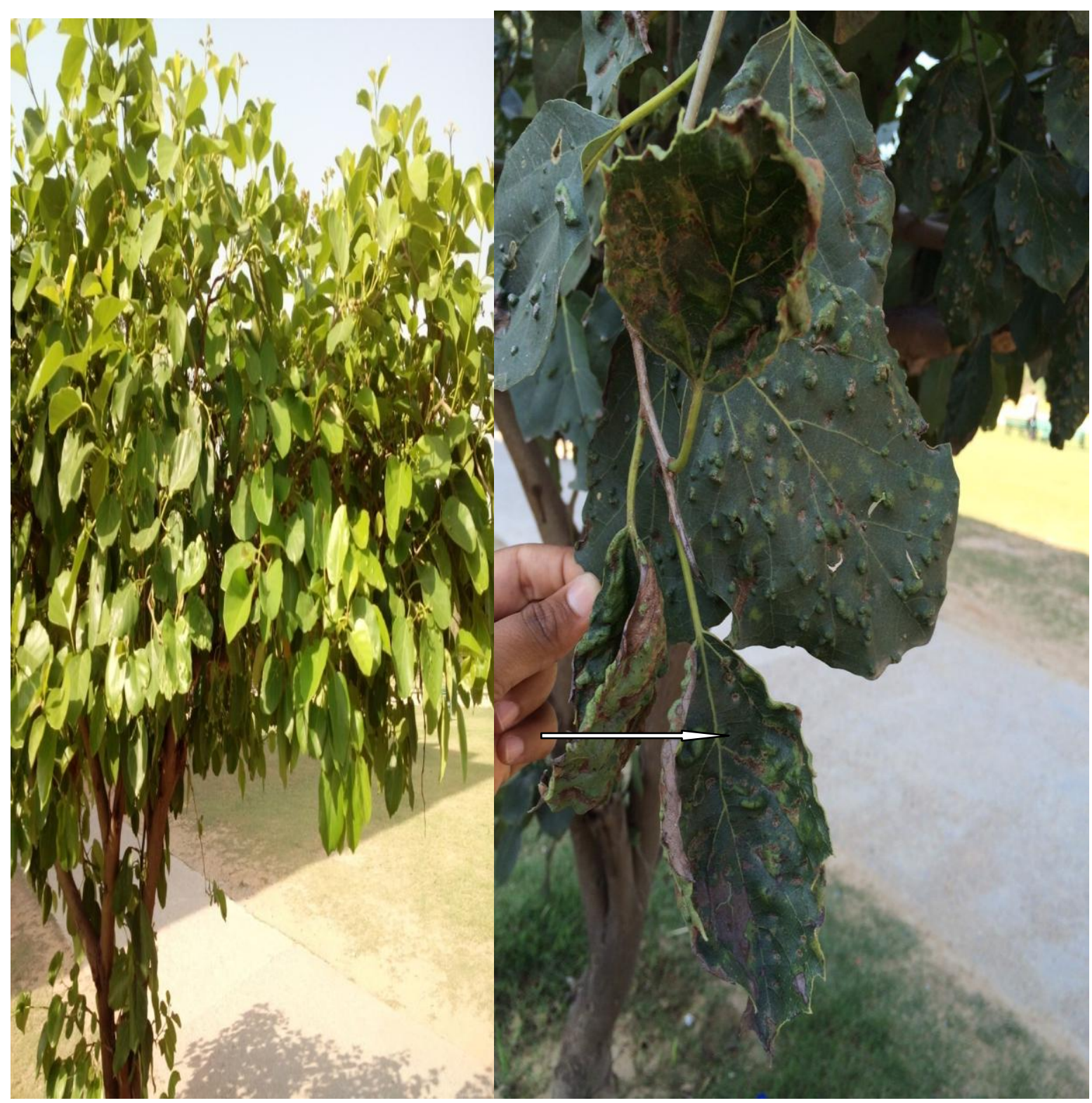


Fig.1B Aeciospores of Aecidium at 40x ; : Aeciospores of Aecidium at 100X through light microscope; D :Aecidium spp infection on dried leaf
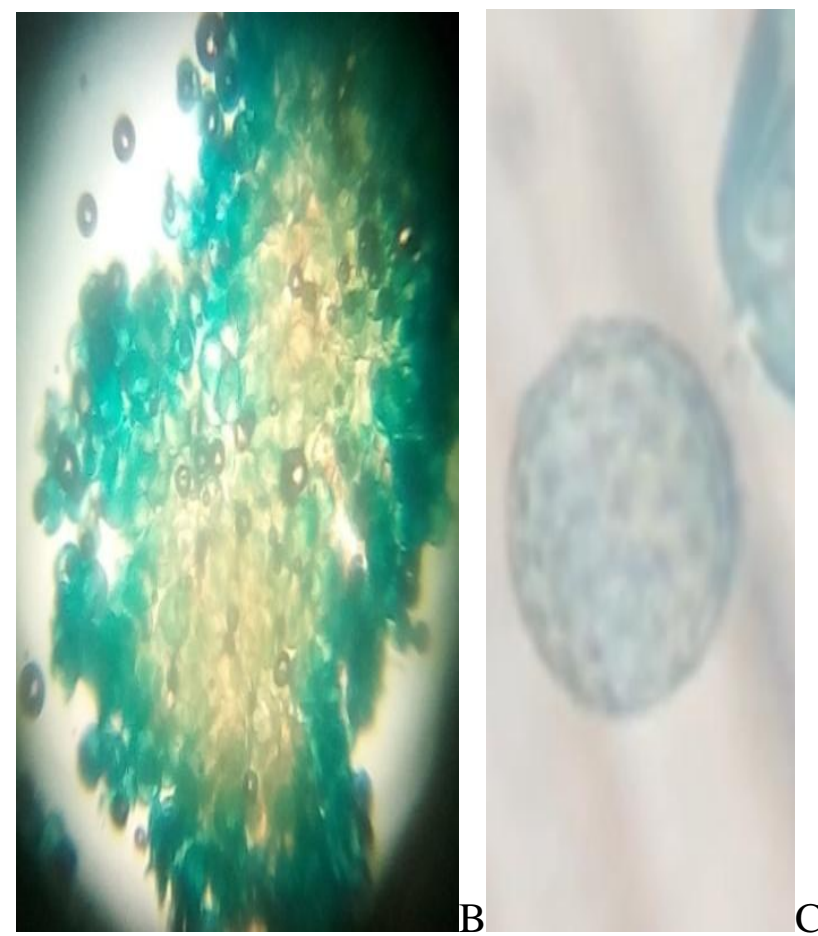

C

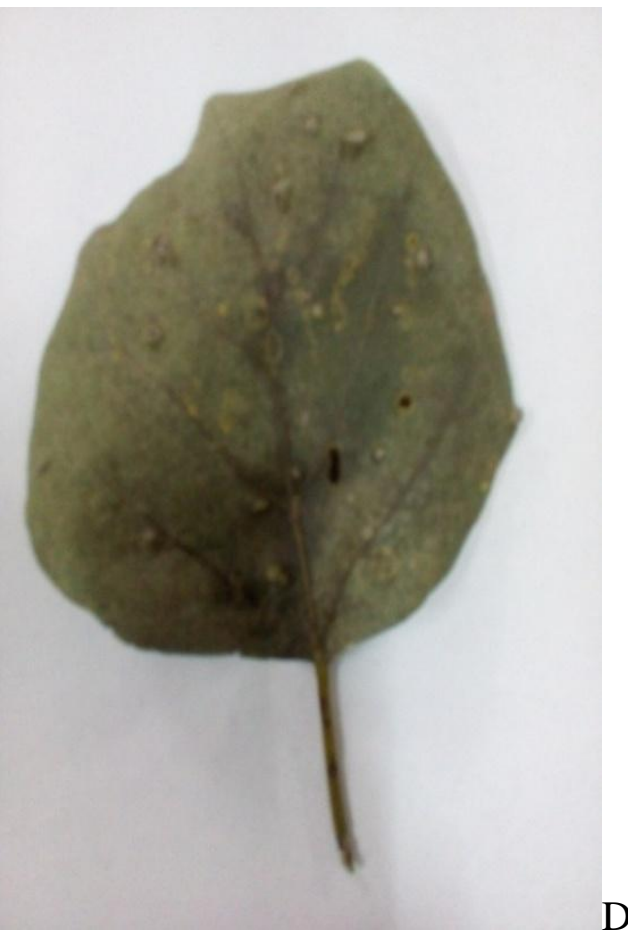

For testing pathogenicity aeciospores were scrapped manually from sporulating pustules (using a scalpel) and placed into sterile distilled water, concentrations were then adjusted to 10 spores/ml using a haemocytometer. Upper leaves of healthy plants were inoculated using an atomised sprayer with $5 \mathrm{ml}$ of the spore suspension in garden. Plants were observed in natural conditions and within 30 days the same distinctive symptoms were developed as were previously seen in the infected plants of C.dichotoma in field. Aeciospores were recovered from pustules on diseased leaves and examined under compound microscope (Magnus -MLX-DX no-101360 of Olympus (India) Pvt Ltd) which have identical morphology to those first observed.

Leaves with different stages of the disease were examined visually and under microscope to study histopathology. On microscopic examination abnormally yellow colour of plant tissues was observed resulting from partial failure to develop chlorophyll. Thus leaving large portions of the leaf unable to photosynthesize, reducing the plant's ability to manufacture food. The lower epidermis cells were disintegrated due to the pressure exerted by the growing fungal structure. As disease progressed, the spots got enlarged and merged to form sunken brown spots. Lastly infected leaves curled and eventually dropped off.

Aecidium sp. infection has been reported from west and south India on Carvia, Hygrophliia (Sathe, 1966); Ocimum, Phlebophyllum, Rostellularia, Diospyros, Hibiscus, Chlorophytrum (Hosagoudar, 2013) and in other countries on different plants, viz., Solanum (Beed et al., 2011); Viburnum (Yun et al., 2013).To the best of our knowledge and belief, this is the first 
report of rust caused by Aecidium spp on C.dichotoma in Haryana (India). Peoples in this area and we are interested in this plant because it is used for many medicinal purposes. Therefore, our report would be useful information for the management of Aecidium spp on C.dichotoma.

\section{Acknowledgments}

Authors are thankful to the Amity University Haryana for providing the facilities and encouragement.

\section{References}

Anjaria, J., Parabia, M., Bhatt, G., Khamar, R. 1997. Nature heals a glossary of selected indigenous medicinal plants of India. SRITI Innovations Ahmedabad; p. 23.

Beed, F., Hotegni Houessou, J.H., Kelly, P., Ezin, V. 2011. First report of Aecidium cantense (potato deforming rust) on Solanum macrocarpon (African eggplant) in Benin. New Disease
Reports, 23: 12.

Hosagoudar, V.B. 2013. My contribution to the fungal knowledge of India. $J$. Threatened Taxa, 5(8): 4129-4348.

Khond, M., Bhosale, J.D., Arif, T., Mandal, T.K., Padhi, M.M., Dabur, R. 2009. Screening of some selected medicinal plants extracts for in-vitro antimicrobial activity. Middle-East J. Sci. Res., 4(4): 271-278.

Parekh, J., Chanda, S. 2007. In vitro screening of antibacterial activity of aqueous and alcoholic extracts of various Indian plant species against selected pathogens from Enterobacteriaceae. Afr. J. Microbiol. Res., 1(6): 92-99.

Sathe, A.V. 1966. Some new reports of aecidium from India. Mycopathologia, 29(1): 118-120.

Yun, Y.H., Son, S.Y. and Kim S.H. 2013. First Report of Aecidium magnatum Anamorph of Uromyces acuminatus Causing Rust on Viburnum sargentii in Korea. Plant Dis., 97(9): 1251.

\section{How to cite this article:}

Narendra Kumar and S.M. Paul Khurana. 2016. Aecidium sp. causing Serious Leaf Rust on Cordia dichotoma G. Forst in Haryana-First Record. Int.J.Curr.Microbiol.App.Sci. 5(8): 55-58. doi: http://dx.doi.org/10.20546/ijcmas.2016.508.006 